Transactions of the American Fisheries Society, 2003, v132, n5, p977-987.

ISSN: 0002-8487 DOI: 10.1577/T02-118

http://afs.allenpress.com/perlserv/?request=get-archive

(C) Copyright by the American Fisheries Society 2003

\title{
Cold, Northern Winters: The Importance of Temperature to Overwinter Mortality of Age-0 White Crappies
}

\author{
Arthur B. McCollum, David B. Bunnell, and Roy A. Stein
}

Aquatic Ecology Laboratory, Department of Evolution, Ecology, and Organismal Biology, The Ohio State University

\begin{abstract}
Survival during the first winter of life can influence the recruitment of many fishes. We used field sampling and laboratory experiments to explore the mechanisms underlying first winter growth and survival of white crappie Pomoxis annularis, which exhibits variable recruitment. We sampled age-0 white crappies from four Ohio reservoirs before winter to evaluate whether large individuals had a greater energy density $(\mathrm{kJ} / \mathrm{g})$ than small ones and whether mean energy density differed among reservoirs. Energy density increased with fish size in all reservoirs, suggesting that small fish could die earlier if energy stores become limiting during winter. Mean energy density varied among reservoirs as well, suggesting that prewinter energy reserves could influence recruitment variability across reservoirs through their effects on winter starvation. Our laboratory experiment evaluated how fish size (small or large), feeding level (starved or fed), and winter severity (mild or severe) interact to influence the growth and survival of age-0 white crappies. The two winter severity treatments represented two extremes for Ohio winters (i.e., mild and severe). We calculated daily individual growth rates for all fish, energy density for a subset of fish, and percent survival across treatments. Winter severity strongly influenced survival: only $47 \%$ of all white crappies survived the severe winter, whereas $97 \%$ survived the mild winter. In the severe winter, neither size nor feeding level influenced mortality. Bomb calorimetry revealed energy density to be similar among fish that died and those that survived the severe winter, suggesting that energy depletion did not cause mortality. Rather, osmoregulatory failure may have occurred during exposure to temperatures colder than $4^{\circ} \mathrm{C}$ for at least 1 week. Thus, the availability of warm $\left(\geq 4^{\circ} \mathrm{C}\right)$, oxygenated water during winter may be critical to the survival of age- 0 white crappies. In the northern portion of their range, winter temperatures may account for some of the recruitment variability common to white crappie populations.
\end{abstract}

Given the high potential for mortality, the first winter of life can be critical to determining year-class strength for both freshwater and marine fishes (Malloy and Targett 1991; Ludsin and DeVries 1997; Hurst and Conover 1998). For sport fishes, understanding the mechanisms underlying first winter mortality, as well as the characteristics of fishes that increase their probability of survival, is essential for successful fisheries management. Among the characteristics of age- 0 fishes, size influences most sources of mortality (Sogard 1997). Starvation, particularly for small age-0 fishes, frequently has been documented as the mechanism underlying winter mortality (Oliver et al. 1979; Johnson and Evans 1990; Miranda and Hubbard 1994a; Ludsin and DeVries 1997). Size-dependent predation also has been hypothesized to regulate winter mortality (see Nielsen 1980; Miranda and Hubbard 1994b; Kristiansen et al. 2000), as small fish are more vulnerable to gape-limited predators than are large ones (Werner and Gilliam 1984). Finally, small fishes appear to be more vulnerable than large ones to osmoregulatory failure, which can result from exposure to extremely cold winter temperatures (Johnson and Evans 1996; but see Lankford and Targett 2001). Relative to starvation and predation, osmoregulatory failure has received less attention (but see Bodensteiner and Lewis 1992; Johnson and Evans 1996).

During winter, age- 0 fishes generally rely on energy stores, as well as energy intake, to 
meet metabolic demands (e.g., Johnson and Evans 1991; Schultz et al. 1998). Large fish are less likely than small ones to exhaust energy stores for the following reasons: they have lower massspecific metabolic rates (Peters 1983) and they frequently have a greater energy density (e.g., Ludsin and DeVries 1997; Post and Parkinson 2001). Probably for these reasons, size-dependent winter starvation has been documented for many taxa, both in field sampling (Miranda and Hubbard 1994a; Post et al. 1998; Sutton and Ney 2001) and in pond and laboratory experiments (Oliver et al. 1979; Post and Evans 1989; Ludsin and DeVries 1997; Schultz et al. 1998). However, size-dependent overwinter mortality is not always documented in field sampling (see Kohler et al. 1993; Jackson and Noble 2000) or in laboratory, outdoor pool, or pond experiments (Toneys and Coble 1979; Isely 1981; Garvey et al. 1998; Jonas and Wahl 1998). Whether sizedependent overwinter mortality occurs probably depends on a suite of factors, including energy depletion, predation, and latitude (see Garvey et al. 1998).

Table 1.-Characteristics of Ohio reservoirs (ordered from south to north) from which age-0 white crappies were collected for energy density estimation during October 17-27, 2000. The mean chlorophyll- $a$ concentration was the grand mean of inflow and outflow integrated water samples collected once per week during May-June 2000 (M. Vanni, Miami University, unpublished data). The total length range and number of individuals $(N)$ pertain to the age-0 white crappies for which energy density was estimated using oxygen bomb calorimetry.

\begin{tabular}{llccccc}
\hline & & & \multirow{2}{*}{$\begin{array}{c}\text { Mean } \\
\text { chlorophyll }\end{array}$} & & \multicolumn{2}{c}{ Energy density estimation } \\
\cline { 5 - 6 } Reservoir & County & Latitude & $a(\mu \mathrm{g} / \mathrm{L})$ & & $\begin{array}{c}\text { Total length } \\
\text { range (mm) }\end{array}$ \\
\hline Caesar Creek & Warren & $39^{\circ} 28^{\prime}$ & 12.1 & 11 & $75-124$ \\
Delaware & Delaware & $40^{\circ} 21^{\prime}$ & 22.6 & 10 & $83-118$ \\
Pleasant Hill & Richland & $40^{\circ} 37^{\prime}$ & 22.7 & 22 & $55-103$ \\
Pymatuning & Ashtabula & $41^{\circ} 31^{\prime}$ & 9.7 & 22 & $50-122$ \\
\hline
\end{tabular}

Exposure to extreme winter temperatures also can contribute to mortality from osmoregulatory failure (Bodensteiner and Lewis 1992; Johnson and Evans 1996; Lankford and Targett 2001). At very cold temperatures (i.e., below $4^{\circ} \mathrm{C}$ ), membrane permeability can change, compromising ion transport mechanisms and resulting in a net loss of critical ions (e.g., $\mathrm{Na}^{+}$; (Wikgren 1953; Morris and Bull 1968), which can eventually lead to death (Johnson and Evans 1996). Size also has been hypothesized to influence susceptibility to osmoregulatory failure (Johnson and Evans 1996) because small fish have a larger gill area, on a per gram basis, than large fish (Hughes 1984). However, large age-0 Atlantic croakers Micropogonias undulatus were more susceptible to cold temperatures than small ones (Lankford and Targett 2001), suggesting that the mechanism underlying size-dependent mortality from cold temperatures requires additional understanding.

In this paper, we explore how different winter conditions influence the growth and survival of age- 0 white crappie Pomoxis annularis. Their native range includes lakes and lowgradient rivers in the north from eastern South Dakota to southeastern Ontario and in the south from eastern Texas to Alabama (Trautman 1957). Ohio is in the northern portion of their native range. Throughout North America, including Ohio, white crappies exhibit variable recruitment success (McDonough and Buchanan 1991; Sammons and Bettoli 1998; Maceina and Stimpert 1998; D. B. Bunnell, unpublished data). In this paper, we evaluate whether the first winter of life could be contributing to recruitment variability in white crappies. To evaluate the potential for size-dependent overwinter mortality, we first sampled age- 0 white crappies from four Ohio reservoirs during October and then quantified whole-fish energy density of both small and large fishes. We sought to quantify whether energy density increased with fish size within reservoirs 
and whether mean energy density of fishes varied between reservoirs. If energy density is size dependent, then small fish should die at a higher rate than large fish, should energy become limiting during winter. To evaluate potential mechanisms underlying winter mortality, we also conducted a laboratory experiment. With a factorial design, we evaluated how feeding level, winter severity, and fish size interact to influence growth and survival of age- 0 white crappies during winter.

\section{Methods}

\section{Energy density of fish from Ohio reservoirs.}

Age-0 white crappies were collected from four Ohio reservoirs during October 17-27, 2000. Reservoirs were selected to span gradients of latitude and productivity (Table 1), which might influence prewinter energy density. Latitude influences the duration of the growing season, and productivity may influence food availability. Fish were collected with Missouri-style trap nets (Colvin and Vasey 1986; 1.3-cm-mesh, with two 0.9-m $\times 1.8-\mathrm{m}$ square frames, four 0.8-m-diameter hoops, and a 21-m lead) that were set over 40 net-nights (10 nets, each net set over 4 nights). Upon capture, fish were placed on ice and returned to the laboratory. From each reservoir, we selected three age- 0 fish per centimeter size-class (if fewer than three were collected, then all were selected), which we then froze in water for later estimation of energetic density. Energy density $(\mathrm{kJ} / \mathrm{g}$ wet mass) of homogenized whole fish was quantified to estimate the relative amount of energy stores (sensu Garvey et al. 1998; Fullerton et al. 2000). Although energy stores are lipids, lipids have approximately 40\% more energy than proteins and 56\% more energy than carbohydrates (Phillips 1969), suggesting that high lipid stores should result in high energy density.

After the selected fish were thawed, prey contents were removed from the stomach and intestines, and the fish were dried individually at $65-70^{\circ} \mathrm{C}$ to a constant mass (Rand et al. 1994). Dried tissue was homogenized to a powder with a mortar and pestle and dried again for $3 \mathrm{~d}$ at $65-70^{\circ} \mathrm{C}$. We ignited two $0.1 \mathrm{~g}$ composite pellets from each fish with an oxygen calorimeter (Parr Instruments, model 1425). A third pellet was ignited if the energy density $(\mathrm{kJ} / \mathrm{g}$ wet mass) of the first two pellets differed by more than 5\%, which occurred in less than $10 \%$ of the samples. On even fewer occasions, if the three pellets all differed from each other by more than $5 \%$, a fourth pellet was ignited. For each fish, energy density was calculated as the mean of two pellets that differed by less than 5\%. For each pellet, initial energy density was corrected for liberated $\mathrm{H}_{2} \mathrm{SO}_{4}$ (using a base titration), sulfur content (using a fixed average), and fuse combustion (Parr Instrument 1993).

\section{Experiment.}

We captured more than 200 age- 0 white crappies with Missouri-style trap nets and bottom trawls (mouth width $=3.7 \mathrm{~m}$; body length $=4.6 \mathrm{~m}$; bar mesh body $=8.4 \mathrm{~mm}$; bar mesh bag $=6.4 \mathrm{~mm}$; same as Pine and Allen 2001) from Pleasant Hill reservoir in Ohio during October $18-27,2000$. Fish were selected from only one reservoir to remove potential genetic effects from the experiment. We chose Pleasant Hill reservoir because of its high abundance of age-0 white crappies and its proximity to our laboratory, which we thought would reduce transportation stress to the fish. Fish were transported to the laboratory in a 600-L hauling tank containing aerated, salted water $(0.5 \% \mathrm{NaCl}$ by mass $)$ to reduce physiological stress. Transport mortality was $0 \%$. On arrival, individuals were transferred to two $1,200-\mathrm{L}$ circular tanks (at 15- 
$17^{\circ} \mathrm{C}$ ) and held for 5-6 weeks, during which time we provided ad libitum blackworms Lumbriculus variegates daily and maintained a photoperiod of about $12 \mathrm{~h}$ dark: $12 \mathrm{~h}$ light.

We evaluated how winter severity (mild or severe), fish size ( $\leq 90 \mathrm{~mm}$ or $>90 \mathrm{~mm}$ total length [TL]), and feeding level (starved or fed) influenced the growth and survival of age- 0 white crappies in a factorial laboratory experiment. The two winter severity treatments were performed in separate temperature-controlled rooms. Winter severity simulated the most mild and severe winters recorded from 11 Ohio reservoirs during 1994 through 2000 (Bunnell, unpublished data; J. E. Garvey, Southern Illinois University, unpublished data). Winter was defined as the period between $10^{\circ} \mathrm{C}$ in the autumn and $10^{\circ} \mathrm{C}$ in the spring; thus, winter severity differed in both duration (severe lasting $173 \mathrm{~d}$, mild lasting $133 \mathrm{~d}$ ) and number of days the temperature was colder than $4^{\circ} \mathrm{C}$ (114 d in severe winter, $6 \mathrm{~d}$ in mild winter). Although the winter regimes derived from Ohio, they probably are similar to winters that occur at longitudes with latitudes similar to those of Ohio (e.g., northern Indiana, Illinois, Missouri, and southern Iowa).

Two temperature loggers per room recorded air temperatures four times per day. We recorded water temperature once per day. In each room, air temperatures began at $15^{\circ} \mathrm{C}$ and were adjusted to decline at a rate of no more than $0.5^{\circ} \mathrm{C} / \mathrm{d}$, depending on temperature treatment. Twelve 25-W bulbs per room provided light; the photoperiod simulated an Ohio winter at latitude $40^{\circ}$ 20'. Each temperature-controlled room housed eight 55-L tanks. Each tank comprised one feeding level and was divided into three compartments. Each compartment housed three fish of the same fish size treatment.

Because collection and acclimation of fish prevented us from beginning the experiment on the first day of winter (i.e., October 22, 2000, in the severe winter), the experiments began on November 29, 2000, and ended on May 29, 2001. During this period, however, we simulated temperature and photoperiod from October 22 to April 12 in the severe winter and from November 16 to March 28 in the mild winter. When the experiment began, 144 fish were weighed (nearest $0.1 \mathrm{~g}$ ) and measured (nearest $\mathrm{mm} \mathrm{TL})$ and then placed into large $(91-120 \mathrm{~mm})$ or small $(70-90 \mathrm{~mm})$ size treatments (i.e., compartments), according to their length. Once fish were placed in all tanks, feeding levels were randomly assigned to each tank. The remaining 17 fish were killed with clove oil $(250 \mathrm{mg} / \mathrm{L})$ for later estimation of energy density, so that initial energy density also was known. Within each compartment, individuals were identified by size, coloration, and fin markings, so that the growth and mortality of individuals could be monitored during the experiment.

Fed fish were offered live blackworms, the same food provided to the acclimating fishes. Because no bioenergetic model had been published for white crappies, we used the bluegill Lepomis macrochirus bioenergetic model (Kitchell et al. 1974) to provide food at a rate of $30 \%$ maximum consumption. To document feeding at a coarse level, we noted whether each individual fed during the first $5 \mathrm{~min}$ after food was added to each tank. Within each winter severity treatment, all sizes of fish were pooled to determine the percent of fish feeding (noting the change in the denominator when mortalities occurred). To maintain water quality, feces were removed and one-third of the water was replaced daily in all treatments. Ammonia $\left(\mathrm{NH}_{4}{ }^{+}\right)$was monitored daily and never approached $0.50 \mathrm{mg} / \mathrm{L}$. Air stones in each compartment ensured a sufficient supply of dissolved oxygen. Fish that died during the experiment were identified, weighed, measured, and frozen in water for later estimates of energy density. At the end of each winter, surviving fish were killed and then also identified individually, weighed, measured, and frozen in water.

Differences in percent survival of all fish in each treatment were evaluated using chi- 
square analyses. For growth, each compartment was a sampling unit; thus, we determined the mean daily growth within each compartment. To account for the differences in the number of days the fish were in the experiment (owing to either mortality or winter treatment), we calculated for each fish its daily growth rate ([final mass - initial mass]/d in experiment). We used a general linear model (Proc GLM; SAS Institute 1999) to determine whether variability in daily growth rate was explained by winter severity, fish size, feeding level, potential two-way interactions, or tank effects nested within the three treatments.

For analyses of energy density, we also used general linear models (Proc GLM; SAS Institute 1999). For fish collected from Ohio reservoirs during October, we set reservoir as a class variable and used fish TL as a covariate. For post hoc comparisons of least-squares mean energy density across reservoirs, we used Tukey-Kramer adjusted multiple comparisons. For experimental fish, we estimated energy density from five fish that survived and five fish that died for each treatment. Here, winter, food, and size were set as class variables; the number of days in the experiment was a covariate in analyses that included fish that died. In all analyses, $\alpha=0.05$ was used to determine significance.

\section{Results}

\section{Energy Density of Field Fish}

Pooling fish from all four Ohio reservoirs, we found that the energy density $(\mathrm{kJ} / \mathrm{g}$ wet mass) of age- 0 white crappies in October increased with TL (Figure $1 ; F_{1,60}=78.71 ; P<0.0001$ ). Thus, large fish had an energetic advantage over small fish before winter in Ohio. Because each reservoir differed in terms of its fish length distribution, we set TL as a covariate and determined that the least-squares mean energy density of fishes differed among reservoirs (Figure $1 ; F_{3,60}=$ 32.21; $P<0.0001)$. Tukey-Kramer adjusted multiple comparisons of least-squares means revealed that the mean energy density of white crappies from Delaware and Caesar Creek was greater than that of individuals from Pleasant Hill and Pymatuning. In the reservoir from which our experimental fish were collected (Pleasant Hill), the energy density of age-0 white crappies was less than that in the Delaware and Caesar Creek reservoirs.

\section{Experiment}

The preexperiment energy density ( $\mathrm{kJ} / \mathrm{g}$ wet mass) of 17 age- 0 white crappies increased with length $\left(F_{1,15}=10.72 ; P=0.005\right)$. Thus, as for fish sampled in the field, large fish had an energetic advantage over small fish at the start of the experiment. However, the energy density of the preexperimental fish was significantly less than that in fish sampled from the reservoir 5 weeks earlier (comparing experimental fish with fish from Pleasant Hill Reservoir in Figure 1; $F_{1,36}=15.98 ; P=0.0003$, using TL as covariate). Compared with age-0 white crappies entering winter in Ohio reservoirs, our experimental fish were in a relatively poor energetic state.

Comparing fish lengths across winter severity treatments showed that the mean initial TL of large fish in the mild winter exceeded that of large fish in the severe winter $\left(t_{70}=2.48 ; P=\right.$ $0.02)$; small fish exhibited no difference in mean initial TL between winters $\left(t_{70}=0.84 ; P=\right.$ 0.40 ). In food treatments, the mean initial TL of starved large and small fish was similar to that of fed large and small fish (large: $t_{70}=0.24, P=0.81$; small: $t_{70}=0.12, P=0.91$ ). Thus, aside from differences between sizes of large fish between winters, our placement of fish into tanks was successful in making fish size similar among treatments.

Winter severity strongly influenced the survival of age- 0 white crappies: $97 \%$ of the fish 
survived the mild winter, whereas only $47 \%$ survived the severe winter $\left(x^{2}=595.0 ; P<0.0001\right)$. Within each winter, neither food treatment (mild: $x^{2}=0.1, P>0.5$; severe: $x^{2}=0.1, P>0.5$ ) nor size (mild: $x^{2}=0.1, P>0.5$; severe: $x^{2}=0.2, P>0.5$ ) influenced survival. Focusing on the severe winter, where considerable mortality occurred, $50 \%$ of all fed white crappies survived and $48.4 \%$ of starved individuals survived. Similarly, $47.1 \%$ of small white crappies survived and $50.0 \%$ of large individuals survived. Mortality first occurred when water temperatures approached $2^{\circ} \mathrm{C}$; peak mortality occurred when water temperatures fell to $1^{\circ} \mathrm{C}$ (Figure 2a). Small fish did not die earlier than large fish, as shown by the finding that the length of fish that died did not increase with days in the experiment (Figure $2 \mathrm{~b} ; F_{1,30}=0.29 ; P=0.60$ ). In addition, food treatment $\left(F_{1,30}=0.21 ; P=0.65\right)$ and the food $\times$ days in the experiment interaction $\left(F_{1,30}=0.16\right.$; $P=0.69)$ were unrelated to length of fish that died.

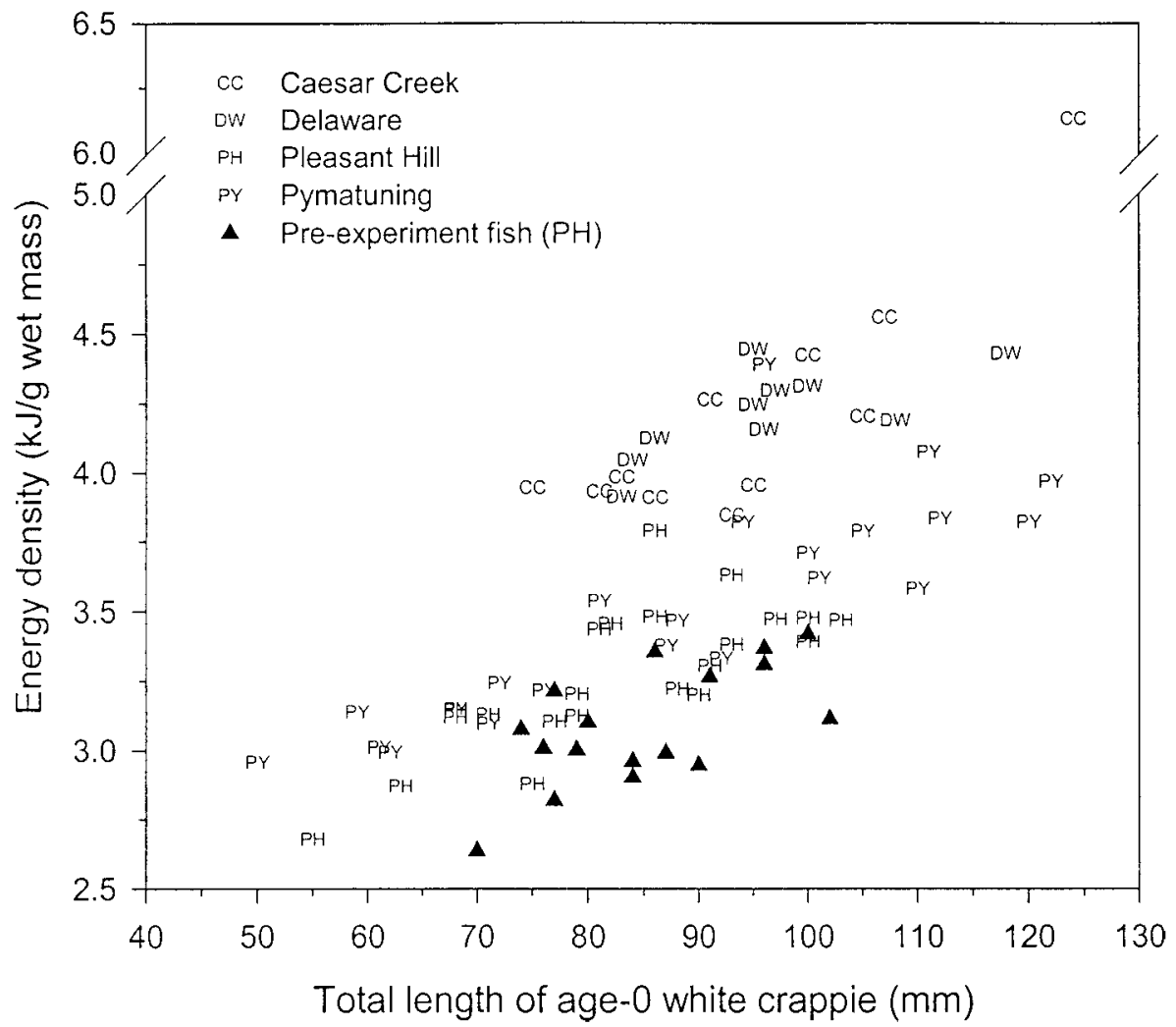

Figure 1.-Energy density (kJ/g wet mass) of age-0 white crappies as a function of total length $(\mathrm{mm})$. Two-letter symbols represent four Ohio reservoirs from which fish were sampled during October 2000 (see Table 1 for details). Triangles represent energy density of the age- 0 white crappies at the beginning of the laboratory experiment, after spending 5-6 weeks in the laboratory. Note the break in the $y$-axis between 5 and $6 \mathrm{~kJ} / \mathrm{g}$.

Both food and fish size influenced daily growth rate. Small fishes had greater daily growth rates than large individuals $\left(F_{1,16}=8.35 ; P=0.01\right)$ and fed fishes had greater daily growth rates than starved individuals $\left(F_{1,16}=58.27 ; P<0.0001\right)$. Growth differences among fish of different sizes occurred because growth rates were not mass specific (i.e., we did not divide change in mass by initial mass). No tank effects were detected $\left(F_{25,16}=0.64 ; P=0.85\right)$. The feeding level $\times$ winter treatment was the only significant interaction $\left(F_{1,16}=6.25 ; P=0.02\right)$ : starved fish in the severe winter had greater daily growth rates than did those in the mild winter, 
whereas fed fish in the severe winter had lower daily growth rates than did those in the mild winter (Figure 3). In terms of mass gained or loss during the experiment, 34\% of all fed fish gained mass. Of the starved fish, 99\% lost mass; one fish was measured to gain mass, which must have resulted from a measuring error either at the start or end of the experiment.

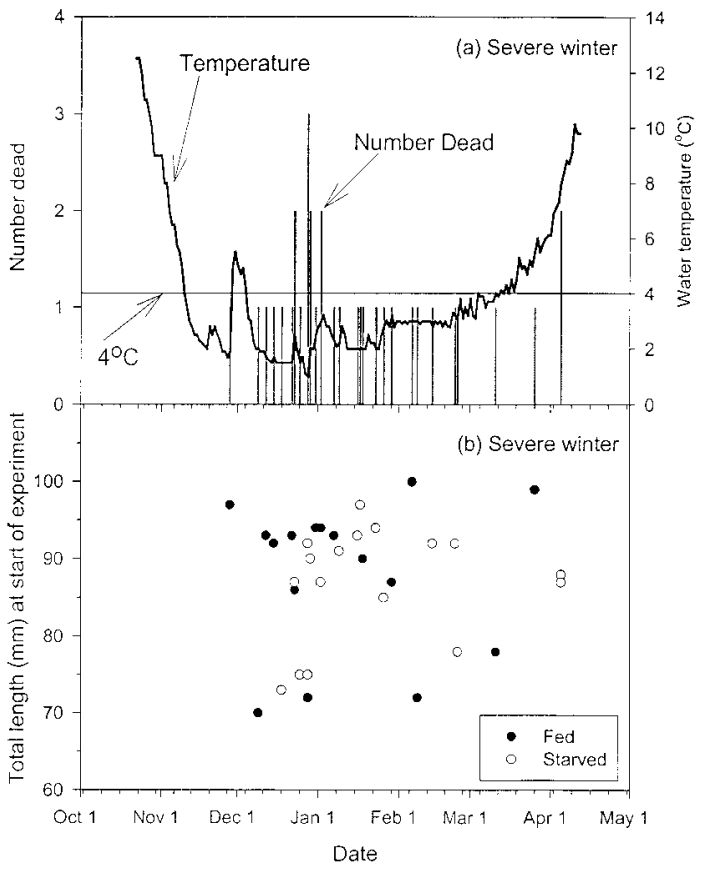

Figure 2.-Mortality of age- 0 white crappies in the severe winter experiment. Because only 2 of 72 fish in the mild winter experiment died, these relationships are not depicted. Panel (a) depicts the number of fish that died (37 fish; vertical bars) during each day of the simulated winter, regardless of feeding level. The solid horizontal line at $4^{\circ} \mathrm{C}$ denotes the temperature below which mortality was frequent. Panel (b) depicts the total length at the start of the experiment of starved and fed fish that died as a function of simulated day of winter. Neither the number of days, food treatment, nor the days $\times$ food interaction predicted the total length of the fish that died.

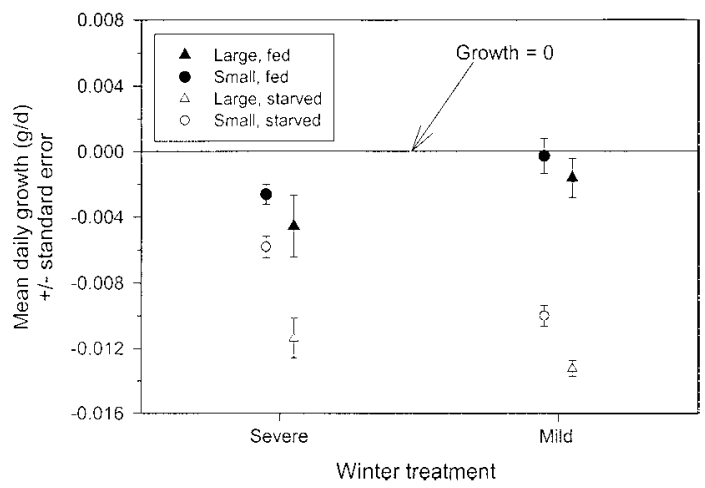

Figure 3.-Mean daily growth rate ([final mass - initial mass]/d in experiment) of different size-classes and feeding levels of age- 0 white crappies as a function of winter treatment. The zero daily growth rate is indicated by a solid horizontal line. The sampling unit was a partition (i.e., the mean of three fish) within one tank; each data point on the graph represents the grand mean of six partitions for each treatment. 


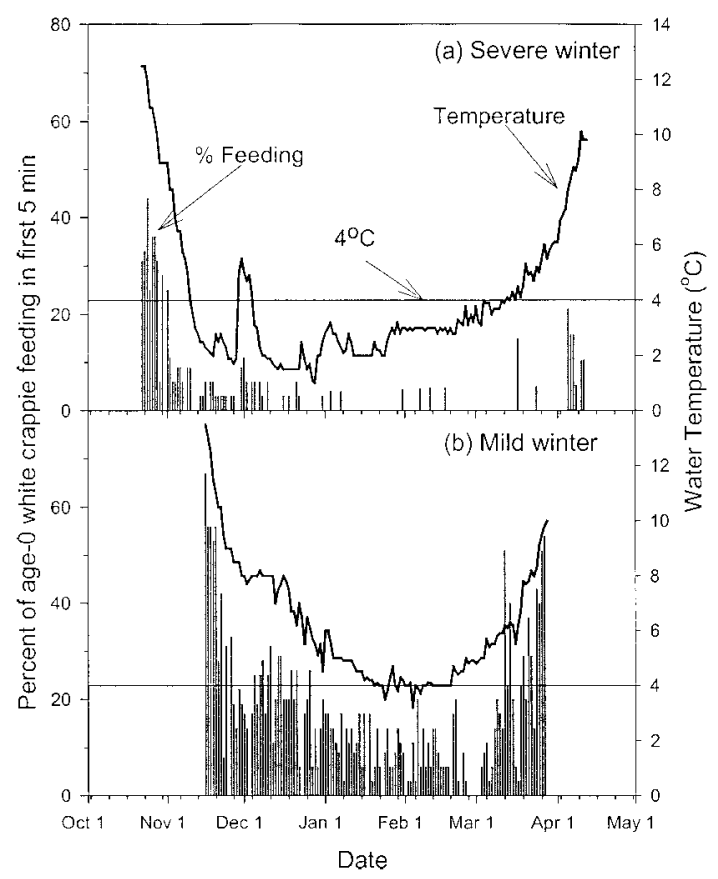

Figure 4.-Percent feeding by age- 0 white crappies (vertical bars) and water temperature (solid line) for the (a) severe and (b) mild winters, as a function of simulated day of winter. Feeding represents the percent of all fish observed to eat in the first $5 \mathrm{~min}$ after food presentation, independent of size. The solid horizontal line at $4^{\circ} \mathrm{C}$ denotes the temperature below which feeding was infrequently observed in the severe winter.

Feeding in the first 5 min during the severe winter was less frequent than during the mild one (Figure $4 a, b)$. In the severe winter, the percent feeding fell below $10 \%$ on November 3 and remained consistently low (including many at 0\%) through April 5 (Figure 4a). As temperatures increased to $10^{\circ} \mathrm{C}$ in the severe winter, the percentage of fish feeding did not concomitantly increase. Conversely, in the mild winter, percent feeding generally ranged from 5\% to $15 \%$ throughout the coldest period (i.e., December 22-March 11; Figure 4b). As temperatures increased to $10^{\circ} \mathrm{C}$, the percentage of fish feeding in the mild winter increased, greatly exceeding the percentage feeding in the severe winter. If we assume that feeding during the first $5 \mathrm{~min}$ reflects feeding for the remainder of the day, then our observations of low consumption by fish in the severe winter may explain why fed fish in the severe winter grew more slowly than did fed fish in the mild winter.

As with daily growth, both feeding level and size treatments influenced energy density $(\mathrm{kJ} / \mathrm{g}$ wet mass $)$ of age- 0 white crappies. Winter $\left(F_{1,36}=1.51 ; P=0.23\right)$ did not influence energy density of survivors. Among survivors, fed fish had a greater energy density than their starved counterparts (Figure 5a; $F_{1,36}=46.11 ; P<0.0001$ ), and large individuals had a greater energy density than small ones $\left(F_{1,36}=6.23 ; P=0.02\right)$. Because only two fish died during the mild winter, we focused on fish from the severe winter to explore the energy density of fish that died during the experiment. Here, variability in energy density was best explained by food because the fed fish that died had marginally greater energy density than did the starved fish that died (Figure $\left.5 \mathrm{~b} ; F_{1,16}=4.03 ; P=0.06\right)$. Neither size $\left(F_{1,16}=2.27 ; P=0.15\right)$ nor days in the experiment $\left(F_{1,16}=0.33 ; P=0.58\right)$ influenced the energy density of fish that died. 


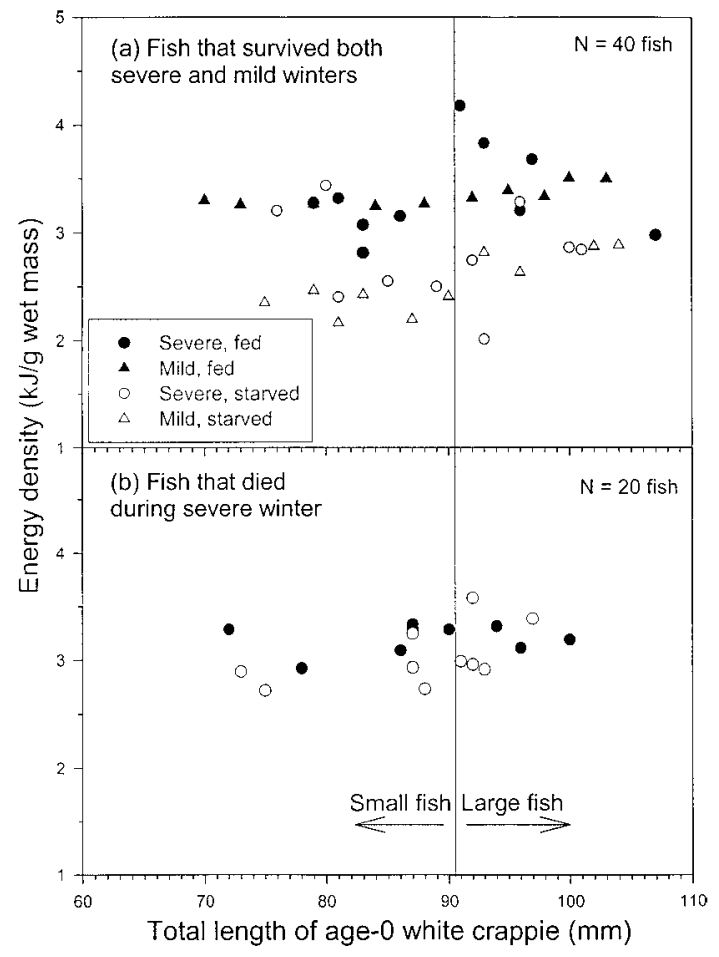

Figure 5.-Energy density (kJ/g wet mass) as a function of total length for age- 0 white crappies that (a) survived both experimental winters and (b) died during the severe winter. Because only 2 fish died in the mild winter (versus 37 fish in the severe winter), we did not quantify their energy density. The vertical line at $90.5 \mathrm{~mm}$ separates the small and large sizes of fish.

To determine whether energy density influenced mortality in the severe winter, we compared the energy density of fish that died and those that survived within each food treatment, using a $t$-test. Pooling across size treatments showed that energy density was similar between both fed fish that died and survived, as well as between starved fish that died and survived (Table 2). We have no evidence that energy density alone caused mortality in the severe winter.

Table 2.-Mean energy density ( $\mathrm{kJ} / \mathrm{g}$ wet mass) of age- 0 white crappies as a function of feeding level as well as whether they survived or died in the severe winter treatment. The $t$-statistic represents results of a test for the effect of the fate of the fish within feeding level treatments. The number of degrees of freedom for both $t$-tests was 18 .

\begin{tabular}{llll}
\hline $\begin{array}{c}\text { Feeding } \\
\text { level }\end{array}$ & Fate of fish & $\begin{array}{l}\text { Mean energy } \\
\text { density (SD) }\end{array}$ & $\begin{array}{c}t \text {-statistic } \\
(P \text {-value })\end{array}$ \\
\hline Fed & Survived & $3.35(0.42)$ & \\
& Died & $3.22(0.14)$ & $0.94(0.37)$ \\
Starved & Survived & $2.78(0.44)$ & \\
& Died & $3.04(0.28)$ & $1.54(0.14)$ \\
\hline
\end{tabular}

\section{Discussion}

The prewinter energy density of age- 0 white crappies increased with size in four Ohio reservoirs. This result suggests that size-dependent overwinter mortality could occur if overwinter mortality was regulated by starvation (i.e., should white crappies have to rely solely on energy reserves). Mean energy density also varied across reservoirs, suggesting that prewinter 
energetic condition might contribute to recruitment variability through its effects on winter starvation. In our experiment, however, neither starvation (i.e., feeding level) nor fish size influenced survival. Rather, the strongest influence was winter severity: survival in the mild winter $(97 \%)$ greatly exceeded that in the severe winter (47\%). The energy density of the experimental fish in the severe winter provided additional support that starvation did not cause mortality. Within a feeding treatment, the mean energy density of fish that died and those that survived did not differ. Our experimental results suggest that significant size-independent mortality should occur in nature when age- 0 white crappies are exposed to water colder than $4^{\circ} \mathrm{C}$ for several weeks.

We hypothesized that winter survival would increase with fish length, as has been documented with several other fish species: white perch Morone americana and yellow perch Perca flavescens (Johnson and Evans 1991); freshwater drum Aplodinotus grunniens (Bodensteiner and Lewis 1992); coho salmon Oncorhynchus kisutch (Quinn and Peterson 1996); largemouth bass Micropterus salmoides (Ludsin and DeVries 1997; Fullerton et al. 2000); Atlantic silverside Menidia menidia (Schultz et al. 1998); and striped bass Morone saxatilis (Sutton and Ney 2001). Large fish should have a survival advantage over small fish because mass-specific metabolic rate declines with size (Peters 1983) and energy reserves typically increase with size (Ludsin and DeVries 1997; Garvey et al. 1998; Post and Parkinson 2001; Sutton and Ney 2001; this paper). In many winter experiments, small fish die earlier than large fish because of starvation (Post and Evans 1989; Johnson and Evans 1991; Hales and Able 2001).

At least two factors suggested that size should influence the probability of white crappie starvation during the experiment. First, large age- 0 white crappies had a greater prewinter energy density than did small ones, in both the field and experiment studies. Second, the energetic condition of all sizes of fish in the experiment was considerably less than that of fish sampled from the field. Thus, in our view, small fishes were most likely to starve during the experiment. However, size offered no survival advantage, as large fish died just as early as small fish. Indeed, nearly all starved white crappies survived $133 \mathrm{~d}$ in the mild winter. These results suggest that size-dependent starvation does not directly influence winter survival in systems at similar latitudes as Ohio, as well as those to the north. Our results also are consistent with previous research in a Wisconsin pond that failed to document size-dependent overwinter mortality in white crappies (Toneys and Coble 1979). To the south, however, size-dependent starvation might still occur. Here, warmer winter temperatures should lead to greater metabolic rates and potential depletion of energy stores.

In nature, large fish also are presumed to survive better than small fish because of sizedependent predation (Nielson 1980; Miranda and Hubbard 1994b; Kristiansen et al. 2000); that is, small fish are more vulnerable to gape-limited predators (Werner and Gilliam 1984). In our experiment, even fed fish did not increase in length during winter, suggesting that autumn length determined spring length. In addition to length, however, end-of-winter energetic condition could influence the vulnerability of age- 0 white crappie to predation; fish in high energetic condition may be able to avoid predators more adeptly (e.g., Jonas and Wahl 1998). In our experiment, food availability regulated energetic condition at the end of winter. Thus, density of zooplankton or benthic macroinvertebrate prey during winter probably dictates the energetic condition of age0 white crappies entering spring, which, in turn, may influence predation risk as piscivores become more active.

Our feeding observations suggest that temperature also may influence the energetic 
condition of age- 0 white crappies entering spring. Fish in the severe winter were less willing than fish in the mild winter to feed when temperatures warmed in late winter. Although we observed feeding for only the first 5 min after food was introduced, this activity probably represented feeding rates throughout the day because fish fed most actively when the blackworms were suspended in the water column (i.e., right after introduction). After $5 \mathrm{~min}$ or so, the blackworms generally settled against the partition and reduced their activity which, in turn, reduced their visibility to the white crappies. In addition, some blackworms nearly always remained in the tanks the following day. Risk of predation in late winter or early spring is probably more a function of energetic condition than fish size, given that no fish grew in length during the experiment. In addition to prey densities, winter temperatures also may contribute to the end-ofwinter condition of age- 0 white crappies in the field.

Prolonged exposure to temperatures colder than $4^{\circ} \mathrm{C}$ caused significant mortality of age- 0 white crappies. Because temperatures in the mild winter were below $4^{\circ} \mathrm{C}$ for only $6 \mathrm{~d}$, we do not know how long age- 0 white crappies can survive in temperatures less than $4^{\circ} \mathrm{C}$. The first mortality in the severe winter occurred after 18 consecutive days colder than $4^{\circ} \mathrm{C}$. On the next day, the cooling system in the severe winter, temperature-controlled room failed, producing the mild-temperature spike observed around the first of December. Although the occurrence of mortalities resumed $11 \mathrm{~d}$ after the unplanned warming period, we attribute these mortalities to prolonged exposure to cold temperatures, not to the abrupt temperature change around the first of December. In fact, our greatest mortality (three fish died) occurred on the coldest day $\left(1^{\circ} \mathrm{C}\right), 27 \mathrm{~d}$ after the temperature-control failure.

Despite our evidence that cold winter temperatures may regulate survival, white crappies range as far north as southern Ontario, Michigan, Wisconsin, Minnesota, and South Dakota, which have colder and longer winters than we simulated in our severe experimental winter. In northern Wisconsin lakes, for example, water temperatures can be less than $4^{\circ} \mathrm{C}$ for $153 \mathrm{~d}$ (Wright et al. 1999). The chemical properties of water, however, should enable age-0 white crappies to occupy $4^{\circ} \mathrm{C}$ throughout winter because water is most dense at $4^{\circ} \mathrm{C}$ (Wetzel 1983). As a result, $4^{\circ} \mathrm{C}$ water should occur in the benthic limnetic zone of northern lakes and reservoirs throughout winter. In the littoral zone and in the upper reaches of the limnetic zone (under the ice), however, colder temperatures should occur, given the shallow depth. Although this experiment predicts that age- 0 white crappies should behaviorally thermoregulate to avoid lethal, sub $-4^{\circ} \mathrm{C}$ temperatures, we do not know that this is indeed the case. Interestingly, however, age- 0 white crappies in Ohio occupy the benthic limnetic zone during autumn (Bunnell, unpublished data); should they remain in that habitat during winter, lethal temperatures may be avoided.

Exposure to extremely cold temperatures during winter influences the survival of other age-0 fishes, including summer flounder Paralichthys dentatus (Malloy and Targett 1991), freshwater drum (Bodensteiner and Lewis 1992), white perch (Johnson and Evans 1996), and Atlantic croakers (Lankford and Targett 2001). Osmoregulatory failure is presumed to be the mechanism involved because membrane permeability changes during colder temperatures, compromising ion transport and resulting in too few critical ions (Morris and Bull 1968). Because small fish have a larger gill area per unit mass (Hughes 1984), they are thought to be more susceptible than large fish to osmoregulatory failure (Johnson and Evans 1996). In our study, mortality was unrelated to size, which suggests that potential differences in gill area were probably inconsequential for large and small age-0 white crappies. Determination of size effects on susceptibility to lethal temperatures apparently will require additional research, given that other recent studies also have found no size effects (Hurst and Conover 2002) or even that small 
individuals have greater cold tolerance than large ones (Lankford and Targett 2001). Nonetheless, for all sizes of age-0 white crappies, prolonged exposure to water temperatures colder than $4^{\circ} \mathrm{C}$ may regulate overwinter mortality, probably through osmoregulatory failure.

\section{Implications for White Crappie Recruitment}

White crappie recruitment to age 1 in Tennessee (Sammons and Bettoli 1998) and to age 2 in Ohio (Bunnell, unpublished data) can be predicted by larval density. If so, then overwinter mortality should be a function of the density of age- 0 fish entering winter and not a function of winter severity (which can vary between reservoirs and between years within a reservoir). Our results provide some support for this prediction. Despite evidence from field sampling that sizedependent overwinter mortality may occur, the experiment yielded no evidence that size or feeding level was important to winter survival. As a result, the experiment supports the prediction that recruitment is set by larval density, insofar as interannual and inter-reservoir variation in prey density and pre-winter distributions of age- 0 white crappie size probably should not influence overwinter survival. In addition, exposure to lethal temperatures should not influence overwinter survival in the southern portion of the white crappie range. For example, temperatures generally do not drop below $5^{\circ} \mathrm{C}$ in large Tennessee reservoirs (P. W. Bettoli, U.S. Geological Survey, personal communication).

In the northern portion of the white crappie range, however, our experimental results are less consistent with the prediction that recruitment is set by larval density. Indeed, interannual and interreservoir variation in winter severity (i.e., cold temperatures) may exist. As a result, the important question is whether age- 0 white crappies can occupy $4^{\circ} \mathrm{C}$ water on the bottom of lakes and reservoirs throughout winter. The only caveat to occupying this deep, thermally appropriate, habitat is the possibility of low oxygen concentrations. In highly productive or ice-covered systems, low oxygen concentrations could occur near the bottom during winter, thus squeezing age-0 white crappies into cooler, more oxygenated waters and compromising their survival (sensu Coutant 1985). Despite our uncertainty regarding habitat selection of age-0 white crappies and oxygen concentrations in $4^{\circ} \mathrm{C}$ water during winter, the present work has revealed that exposure to water temperature colder than $4^{\circ} \mathrm{C}$ causes considerable size-independent mortality, providing a potential mechanism by which winter may regulate recruitment of white crappies in the northern portion of their range.

\section{Acknowledgments}

We are grateful to J. Pyzoha and S. Thomas for their time and effort estimating energy density and to A. Peer and A. Spencer for their help in the field and laboratory. Thanks to B. Pine for teaching us how to sample age-0 white crappies with a bottom trawl. M. Allen, E. Marschall, S. Sammons, and one anonymous reviewer provided extremely helpful comments. Thanks to P. Bettoli, J. Boxrucker, J. Garvey, G. Kim, and E. Scott for increasing our knowledge of winter temperatures across the range of white crappies. This research was funded by Federal Aid in Sport Fish Restoration Project F-69-P, administered jointly by U.S. Fish and Wildlife Service and Ohio Department of Natural Resources, Division of Wildlife, and the Department of Evolution, Ecology, and Organismal Biology at the Ohio State University.

\section{References}

Bodensteiner, L. R., and W. M. Lewis. 1992. Role of temperature, dissolved-oxygen, and backwaters in the winter survival of fresh-water drum Aplodinotus grunniens in the Mississippi River. Canadian Journal of Fisheries 
and Aquatic Sciences 49:173-184.

Colvin, M. A., and F. W. Vasey. 1986. A method of qualitatively assessing white crappie populations in Missouri reservoirs. Pages 79-85 in G. E. Hall and M. J. Van Den Avyle, editors. Reservoir fisheries management: strategies for the 80‘s. American Fisheries Society, Southern Division, Reservoir Committee, Bethesda, Maryland.

Coutant, C. C. 1985. Striped bass, temperature, and dissolved oxygen: a speculative hypothesis for environmental risk. Transactions of the American Fisheries Society 114:31-61.

Fullerton, A. H., J. E. Garvey, R. A. Wright, and R. A. Stein. 2000. Overwinter growth and survival of largemouth bass: interactions among size, food, origin, and winter severity. Transactions of the American Fisheries Society 129:1-12.

Garvey, J. E., R. A. Wright, and R. A. Stein. 1998. Overwinter growth and survival of age-0 largemouth bass Micropterus salmoides: revisiting the role of body size. Canadian Journal of Fisheries and Aquatic Sciences 55:2414-2424.

Hales, L. S., and K. W. Able. 2001. Winter mortality, growth, and behavior of young-of-the-year of four coastal fishes in New Jersey (USA) water. Marine Biology 138:45-54.

Hughes, G. M. 1984. General anatomy of the gills. Pages 1-72 in W. S. Hoar and D. J. Randall, editors. Fish physiology, volume 10A. Academic Press, New York.

Hurst, T. P., and D. O. Conover. 1998. Winter mortality of young-of-year Hudson River striped bass Morone saxatilis: size-dependent patterns and effects on recruitment. Canadian Journal of Fisheries and Aquatic Sciences 55:1122-1130.

Hurst, T. P., and D. O. Conover. 2002. Effects of temperature and salinity on survival of young-of-the-year Hudson River striped bass (Morone saxatilis): implications for optimal overwintering habitats. Canadian Journal of Fisheries and Aquatic Sciences 59:787-795.

Isely, J. J. 1981. Effects of water temperature and energy reserves on overwinter mortality in young-of-the-year largemouth bass (Micropterus salmoides). Master's thesis. Southern Illinois University, Carbondale.

Jackson, J. R., and R. L. Noble. 2000. First-year cohort dynamics and overwinter mortality of juvenile largemouth bass. Transactions of the American Fisheries Society 129:716-726.

Johnson, T. B., and D. O. Evans. 1990. Size dependent winter mortality of young-of-the-year white perch: climate warming and invasion of the Laurentian Great Lakes. Transactions of the American Fisheries Society 119:301-310.

Johnson, T. B., and D. O. Evans. 1991. Behavior, energetics, and associated mortality of young-of-year white perch Morone americana and yellow perch Perca flavescens under simulated winter conditions. Canadian Journal of Fisheries and Aquatic Sciences 48:672-680.

Johnson, T. B., and D. O. Evans. 1996. Temperature constraints on overwinter survival of age-0 white perch. Transactions of the American Fisheries Society 125:466-471.

Jonas, J. R., and D. H. Wahl. 1998. Relative importance of direct and indirect effects of starvation for young walleyes. Transactions of the American Fisheries Society 127:192-205.

Kitchell, J. F., J. F. Koonce, R. V. O’Neill, H. H. Shugart, Jr., J. J. Magnuson, and R. S. Booth. 1974. Model of fish biomass dynamics. Transactions of the American Fisheries Society 103:786-798.

Kohler, C. C., R. J. Sheehan, and J. J. Sweatman. 1993. Largemouth bass hatching success and first-winter survival in two Illinois reservoirs. North American Journal of Fisheries Management 13:125-133.

Kristiansen, T. S., H. Ottera, and T. Svasand. 2000. Size-dependent mortality of juvenile reared Atlantic cod released in a small fjord. Journal of Fish Biology 56:792-801.

Lankford, T. E., and T. E. Targett. 2001. Low-temperature tolerance of age-0 Atlantic croakers: recruitment implications for U.S. mid-Atlantic estuaries. Transactions of the American Fisheries Society 130:236-249.

Ludsin, S. A., and D. R. DeVries. 1997. First-year recruitment of largemouth bass: the interdependency of early life stages. Ecological Applications 7:1024-1038.

Maceina, M. J., and M. R. Stimpert. 1998. Relations between reservoir hydrology and crappie recruitment in Alabama. North American Journal of Fisheries Management 18:104-113.

Malloy, K. D., and T. E. Targett. 1991. Feeding, growth and survival of juvenile summer flounder Paralichthys dentatus: experimental analysis of the effects of temperature and salinity. Marine Ecology Progress Series 72:213-223.

McDonough, T. A., and J. P. Buchanan. 1991. Factors affecting abundance of white crappies in Chickamauga Reservoir, Tennessee, 1970-1989. North American Journal of Fisheries Management 11:513-524.

Miranda, L. E., and W. D. Hubbard. 1994a. Length-dependent winter survival and lipid composition of age-0 largemouth bass in Bay Springs Reservoir, Mississippi. Transactions of the American Fisheries Society 
$123: 80-87$

Miranda, L. E., and W. D. Hubbard. 1994b. Winter survival of age-0 largemouth bass relative to size, predators and shelter. North American Journal of Fisheries Management 14:790-796.

Morris, R., and J. M. Bull. 1968. Studies on freshwater osmoregulation in the ammocoete of Lampetra planeri (Bloch). Journal of Experimental Biology 48:597-609.

Nielsen, L. A. 1980. Effect of walleye (Stizostedion vitreum vitreum) predation on juvenile mortality and recruitment of yellow perch (Perca flavescens) in Oneida Lake, New York. Canadian Journal of Fisheries and Aquatic Sciences 37:11-19.

Oliver, J. D., G. F. Holeton, and K. E. Chua. 1979. Overwinter mortality of fingerling smallmouth bass in relation to size, relative energy stores, and environmental temperatures. Transactions of the American Fisheries Society 108:130-136.

Parr Instrument. 1993. 1672 Thermometer operating instruction manual. Parr Instrument, Moline, Illinois.

Peters, R. H. 1983. The ecological implications of body size. Cambridge University Press, Cambridge, UK.

Phillips, A. M. 1969. Nutrition, digestion, and energy utilization. Pages 391-432 in W. S. Hoar and D. J. Randall, editors. Fish physiology, volume 1. Academic Press, New York.

Pine, W. E., and M. S. Allen. 2001. Differential growth and survival of weekly age-0 black crappie cohorts in a Florida lake. Transactions of the American Fisheries Society 130:80-91.

Post, J. R., and D. O. Evans. 1989. Size-dependent overwinter mortality of young-of-the-year yellow perch Perca flavescens: laboratory, in situ enclosures, and field experiments. Canadian Journal of Fisheries and Aquatic Sciences 46:1958-1968.

Post, D. M., J. F. Kitchell, and J. R. Hodgson. 1998. Interactions among adult demography, spawning date, growth rate, predation, overwinter mortality, and recruitment of largemouth bass in a northern lake. Canadian Journal of Fisheries and Aquatic Sciences 55:2588-2600.

Post, J. R., and E. A. Parkinson. 2001. Energy allocation strategy in young fish: allometry and survival. Ecology 82:1040-1051.

Quinn, T. P., and N. P. Peterson. 1996. The influence of habitat complexity and fish sire on over-winter survival and growth of individually marked juvenile coho salmon Oncorhyncus kisutch in Big Beef Creek, Washington. Canadian Journal of Fisheries and Aquatic Sciences 53:1555-1564.

Rand, P. S., B. F. Lantry, R. O’Gorman, R. Owens, and D. J. Stewart. 1994. Energy density and size of pelagic prey fishes in Lake Ontario, 1978-1990: implications for salmonine energetics. Transactions of the American Fisheries Society 123:519-534.

Sammons, S. M., and P. W. Bettoli. 1998. Larval sampling as a fisheries management tool: early detection of yearclass strength. North American Journal of Fisheries Management 18:137-143.

SAS Institute. 1999. SAS/STAT user's guide, version 8. SAS Institute, Cary, North Carolina.

Schultz, E. T., D. O. Conover, and A. Ehtisham. 1998. The dead of winter: size-dependent variation and genetic differences in seasonal mortality among Atlantic silverside (Atherinidae: Menidia menidia) from different latitudes. Canadian Journal of Fisheries and Aquatic Sciences 55:1149-1157.

Sogard, S. M. 1997. Size-selective mortality in the juvenile stage of teleost fishes: a review. Bulletin of Marine Science 60:1129-1157.

Sutton, T. M., and J. J. Ney. 2001. Size-dependent mechanisms influencing first-year growth and winter survival of stocked striped bass in a Virginia mainstream reservoir. Transactions of the American Fisheries Society 130:1-17.

Toneys, M. L., and D. W. Coble. 1979. Size-related, first winter mortality of freshwater fishes. Transactions of the American Fisheries Society 108:415-419.

Trautman, M. B. 1957. The fishes of Ohio. Ohio State University Press, Columbus.

Werner, E. E., and J. F. Gilliam. 1984. The ontogenetic niche and species interactions in size-structured populations. Annual Review of Ecology and Systematics 15:393-425.

Wetzel, R. G. 1983. Limnology, 2nd edition. Saunders, Philadelphia.

Wikgren, B. J. 1953. Osmoregulation in some aquatic animals with special reference to the influence of temperature. Acta Zoologica Fennica 71:1-93.

Wright, R. A., J. E. Garvey, A. H. Fullerton, and R. A. Stein. 1999. Predicting how winter affects energetics of age0 largemouth bass: how do current models fare? Transactions of the American Fisheries Society 128:603612. 